\title{
New Insights into Gold Mineralization at the Yellowknife City Gold Project, Northwest Territories from Synchrotron micro-XRF and PXRD
} \author{
Banerjee $^{1^{*}}$ \\ 1. Department of Earth Sciences, Western University, London, Canada. \\ 2. Yamana Gold Inc., Toronto, Ontario, Canada. \\ 3. LISA CAN Analytical Solutions, Inc., Saskatoon, Canada. \\ 4. TerraX Minerals, Inc., Vancouver, Canada. \\ * Corresponding author: neil.banerjee@uwo.ca
}

Ramjay J. Botor ${ }^{1}$, Hannah Cavallin ${ }^{1,2}$ Trevor J. Flynn ${ }^{1}$, Lisa L. Van Loon ${ }^{1,3}$, Alan Sexton ${ }^{4}$ and Neil R.

The Yellowknife City Gold Project (YCGP) is a $771.6 \mathrm{~km}^{2}$ property located at the southern tip of the Yellowknife Greenstone Belt (YGB). It is a well-studied, north-south trending Archaean granitegreenstone-terrane in the Slave Craton situated near Yellowknife, Northwest Territories [1, 2]. TerraX Minerals, Inc. is exploring the extensions of the gold-bearing shear zones north, south, and east of the historic Con and Giant gold mines. Gold is best developed in quartz veins hosted by both metasedimentary and metavolcanic rocks [3], and it is commonly associated with pyrite and arsenopyrite [4]. The Northbelt portion of the property contains extensions of gold mineralized shear zones that are on strike with the Con and Giant gold mines. These shear zones are proximal to the north-south trending Yellowknife River Fault Zone, which is believed to be a conduit for fluid percolation and mineralization during metamorphic processes in the Late Archaean Era [5]. Seven mineralization styles occur within in the YCGP. All show common features such as the presence of pyrite, arsenopyrite, sphalerite, and galena, which are hosted by multi-stage quartz-carbonate veining [6]. Gold grades vary from lower grade (i.e., from 0.1 to $5 \mathrm{~g} / \mathrm{t} \mathrm{Au}$ ) hosted by intermediate to felsic volcanic rocks, to higher grade quartz veins (i.e., 30 to $200 \mathrm{~g} / \mathrm{t} \mathrm{Au}$ ), hosted in mafic volcanic host rocks [6].

Synchrotron radiation X-ray fluorescence spectroscopy (SR-XRF) was performed on drill cores and rock slabs in-situ without extensive sample preparation at the IDEAS beamline at the Canadian Light Source (CLS) in Saskatoon, SK to create 2D trace element maps that reveal spatial and structural associations with gold mineralization. The samples selected consist of rock slabs from the Geological Survey of Canada Extech III Project and drill cores from TerraX from seven gold prospects that represent mineralized sections of the YGB [7]. 2D SR-XRF maps of rock slabs and drill cores up to $10 \mathrm{x} 4 \mathrm{~cm}$ were produced by rastering across the sample, using beam spot sizes of 500x500 $\mu \mathrm{m}, 1 \times 1 \mathrm{~mm}$, and 2x2 $\mathrm{mm}$, with a 1 second dwell time. The incident X-ray energy was set to $13750 \mathrm{eV}$. A Ketek ${ }^{\circledR}$ AXAS-M single element SDD was used to measure the XRF signal. The distance between the sample and the detector was set to $15 \mathrm{~cm}$ for all samples. SR-XRF data analysis was done with Peakaboo 4 and PyMCA $[8,9]$. Maps of key elements, such as, Fe, and $\mathrm{Au}$, were compared to investigate geochemical associations, as well as macro-scale textures and alteration patterns, and associations of Au with other elements. SR-PXRD data collection on corresponding powders was conducted at the CMCF beamline 08BM-1 at the CLS using established setup parameters for geologic materials [10]. SR-PXRD was used to identify alteration mineralogy and major deposit characterizing minerals.

Evidence from both SR-XRF and SR-PXRD studies reveal that mineralization in the drill cores from the YCGP are likely related to the same mineralizing system as the historic Con and Giant mines. Alteration mineral assemblages, mineralized textures, and overprinting relationships are similar in samples from 
both the YCGP and YGB, such as pyrite-arsenopyrite overprinted by later sphalerite-galena, sericitechlorite overprinting earlier sulphides, and late quartz-carbonate veining. Other textures common in the rocks are quartz-carbonate and sulphide veining, foliation, and heavy sericite overprinting. Gold is associated with sulphides (As-Fe), quartz-carbonate (Ca), and sericite-chlorite (K-Ca-Fe). Similarities between the prospects in the YCGP suggest they formed as part of a single, long-lived mineralizing system, with common features such as sulphides overprinted by sericite-chlorite and cut by later quartzcarbonate veining in both metavolcanic and metasedimentary host rocks [11].

\section{References:}

[1] BL Cousens, J. Geology 108 (2000), p. 181.

[2] CE Isachsen and SA Bowring, Geology 22 (1994), p. 917.

[3] WK Fyson, Canadian Journal of Earth Sciences 24 (1986), p. 698.

[4] LC Coleman, Economic Geology 52 (1957), p. 400.

[5] L Ootes et al, Economic Geology 106 (2011), p. 713.

[6] GeoVector Management, Inc. (2018).

[7] G Kirkham et al., Geological Survey of Canada Open File 1583 (2003), (accessed Feb. 22, 2019)

[8] N Sherry et al., Science Studio Project Summary. (2012), http://sciencestudio.net/summary.php.

[9] V Solé, et al., Spectrochimica Acta Part B 62 (2007), p. 63.

[10] N Banerjee et al., Microscopy \& Microanalysis 24(Suppl2) (2018) p.518.

[11] Research described in this paper was performed at the Canadian Light Source, which is supported by the CFI, NSERC, the Univ. of Saskatchewan, the Government of Saskatchewan, Western Economic Diversification Canada, the NRC, and the CIHR. The authors acknowledge funding from NSERC and TerraX Minerals, Inc. We thank D. Muir, M. Fodje, \&S. Labiuk for their support in conducting the experiments.
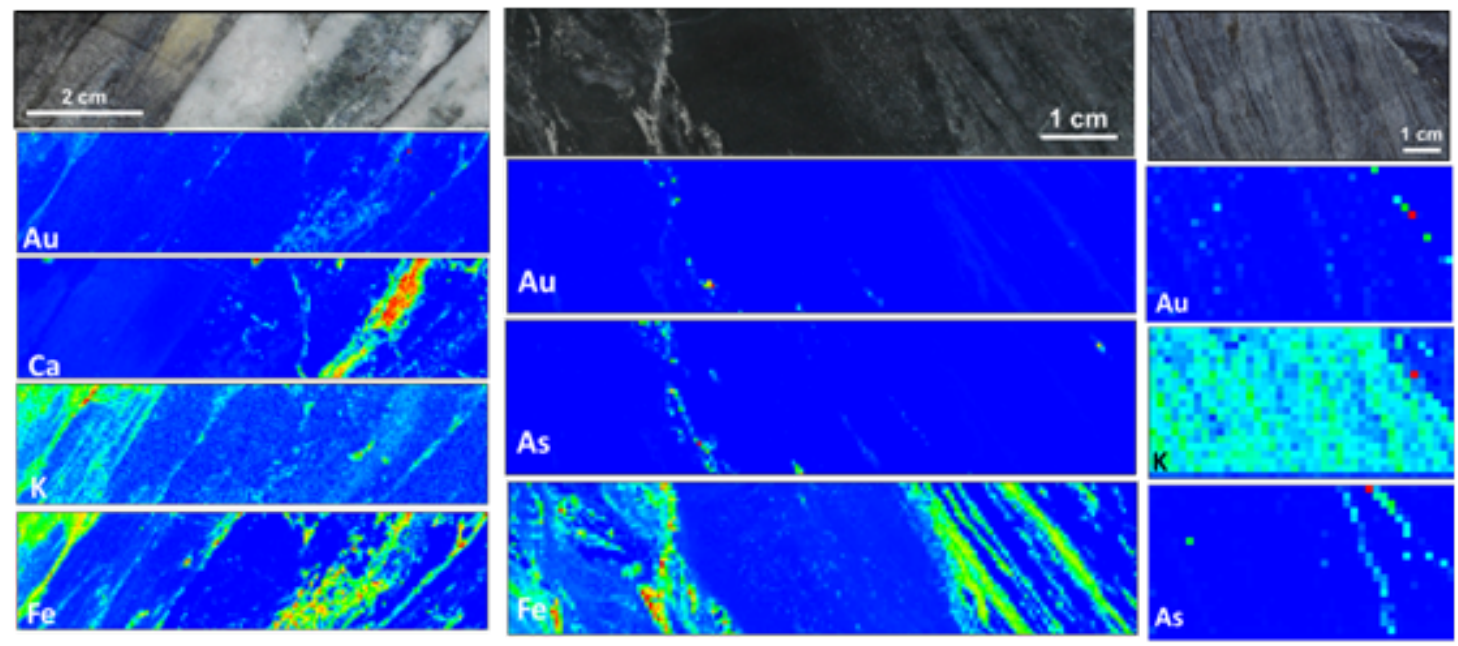

Figure 1. SR-XRF single-element maps of (left) $\mathrm{Au}$ associated with $\mathrm{Ca}$, (middle) Au associated with Fe-As, and (right) Au associated with K. Textures can also be seen, such as foliation and heavy overprinting, shown by (left) laminated and (right) massive $\mathrm{K}$ distribution. 